\author{
Kinga Tutak \\ Uniwersytet Jagielloński, Kraków \\ kingatutak@interia.pl
}

\title{
RACZYŁ ŁUKASZA GÓRNICKIEGO W ŚWIETLE TEORII KULTURY JĘZYKA AUTORA DWORZANINA POLSKIEGO
}

Słowa klucze: Łukasz Górnicki, kultura języka, czasownik raczyć

Keywords: Łukasz Górnicki, linguistic culture, the verb raczyć 'to deign'

Celem artykułu jest charakterystyka „drobiazgu piśmienniczego" (Kozielewski 1929: 55) Raczył Łukasza Górnickiego (1527-1603). Utworowi temu nie poświęcono do tej pory wystarczająco dużo uwagi ${ }^{1}$, choć świadczy o językoznawczych zainteresowaniach Górnickiego, podobnie jak pierwsza księga Dworzanina polskiego czy rozprawka o ortografii ${ }^{2}$, która weszła w skład pracy zbiorowej wydanej przez Jana Januszowskiego jako Nowy karakter polski. Miniatura Raczył ukazała się w roku 1598,

1 Zob. Pollak 1961; Rzepka, Walczak 1993; Lichański 1998.

2 Spośród kilkudziesięciu artykułów i rozpraw wymieniam moim zdaniem najważniejsze: Pollak 1928, 1932, 2004; Sinielnikoff 1962; Walczak 1992, 1995; Noworolska, Stec 1993; Gruchała 1997; Salwa 2005;

Gallewicz 2006. O projekcie ortograficznym Górnickiego zob. np. Klemensiewicz 1981; Kaczmarczyk 1991; Berlińska 1993.

3 Utwór Górnickiego różnie jest przez znawców jego twórczości określany. O kłopotach genologicznych mogą świadczyć takie nazwy gatunkowe jak: drobiazg satyryczny (Chmielowski 1886: XXVI), drobiazg piśmienniczy (Kozielewski 1929: 55), traktacik obyczajowy (Barycz 1950: XLII), gawęda (Pollak 1961: 40), broszura (Rzepka, Walczak 1993: 232). Raczył jest, według mnie, miniaturą literacką, czyli utworem literackim o drobnych rozmiarach, realizującym w wyrazistym skrócie typową strukturę gatunków lub odmian rozwijanych zwykle w obszerniejszej formie (Sierotwiński 1986: 144), tu: mowy jako podstawowego gatunku oratorstwa (Otwinowska 1998: 564). Zagadnienie zróżnicowania gatunkowego średniopolskich wypowiedzi o języku polskim stanie się przedmiotem odrębnego opracowania. 
tj. 32 lata po Dworzaninie, najważniejszym dziele Górnickiego, które - zdaniem Romana Pollaka (1984: 218) - zajmuje czołowe miejsce w rozwoju polszczyzny. W pierwszej księdze Dworzanina polskiego Górnicki przedstawił swoją wizję kultury języka. Doskonale wpisuje się w nią utwór poświęcony czasownikowi raczyć.

Artykuł otwiera próba rekonstrukcji teorii kultury języka według Górnickiego. Druga część szkicu przynosi językowo-stylistyczną charakterystykę miniatury $R a$ czył. Część trzecia, oparta na kwerendzie słownikowej, pokazuje zmiany zachodzące w funkcjonowaniu czasownika raczyć (głównego „bohatera” utworu Górnickiego) od najstarszych poświadczeń po wiek XX.

1. W czasach Górnickiego, to znaczy w wieku XVI, zwłaszcza w jego drugiej połowie, wiele uwagi poświęcano językowi, problemom gramatyki, ortografii, retoryki, przekładu z jednego języka na inny. Kwestie związane z rozwojem języka i retoryki były przedmiotem studiów, ale i zaciekłych sporów, o czym świadczy polemika Jana Sandeckiego-Maleckiego ze Stanisławem Murzynowskim i Janem Seklucjanem (zob. Rospond 1949; Klemensiewicz 1981; Walczak 1995) albo dyskusja między Jakubem Górskim i Benedyktem Herbestem (zob. Werpachowska 1987; Tutak 2013). Górnicki z nikim się nie spierał, jego dzieło nie ma charakteru polemicznego, ale stanowi pierwszą całościową teorię kultury języka, teorię konsekwentną, przemyślaną, wewnętrznie spójną i w dużej mierze oryginalną (Rzepka, Walczak 1993: 213). Jej rekonstrukcji dokonam, przywołując główne dzieło Górnickiego, tj. Dworzanina polskiego (1566). Dworzanin stanowi adaptację Il libro del Cortegiano Baldassarra Castiglionego z $1528 \mathrm{r}$. Górnicki postanowił wpisać tekst Castiglionego w realia bliskie polskiemu odbiorcy, co doprowadziło do wielu zmian w samej „treści” utworu (Gallewicz 2006: 9-10). Natomiast nie zmienił Górnicki metody kompozycyjnej dzieła, posłużył się dialogiem, formą literacką otwartą i elastyczną, pozwalającą na ukazanie opinii wyrażających odmienne punkty widzenia, bez konieczności dojścia do niepodważalnych konkluzji, co umożliwiało autorowi zachowanie neutralnego stanowiska (ibid.: 38). Wypowiedzi odautorskie pojawiają się w Dworzaninie, ale należą do obudowy paratekstowej dzieła, występują w dedykacji skierowanej do króla Zygmunta Augusta podpisanej 18 VII 1565 r., we wstępach do poszczególnych ksiąg oraz w epilogu księgi czwartej. Na uwagę zasługuje zwłaszcza wstęp do pierwszej księgi, który ma charakter przedmowy do czytelnika i stanowi swoisty wykład zasad sztuki pisarskiej Górnickiego (Lichański 1998: 102). Okazuje się, że Górnicki przeprowadził filologiczne, źródłowe badania, a wszelkie zmiany w stosunku do oryginału były uzasadnione. Dążył bowiem do tego, by przekład oddawał sens oryginału, a nie stanowił jego dosłowną, niewolniczą kopię. Deklaruje:

Zgoła niechaj to każdy wie/ iżem ja Polakom pisząc/ Polakom folgować chciał: przeto opuściłem siła rzeczy/ które abo nie należały Polszcze [tj. nie odpowiadały stosunkom w Polsce - K.T.]/ abo rzecz zatrudnić/ a poczciwe uszy obrazić mogły [...] (Górnicki 1566: $\left.\mathrm{B}_{3}-\mathrm{B}_{3} \mathrm{v}\right)$. 
Procesowi adaptacyjnemu podlegały również przemyślenia o języku (we włoskim pierwowzorze o języku włoskim). Według R. Pollaka fragmenty poświęcone językowi w Dworzaninie (choć są - przynajmniej po części - od Castiglionego zależne) odbiegają od oryginału, są o wiele krótsze (jeśli wywody o języku u Castiglionego obejmują około 500 wierszy druku, to u Górnickiego jest ich około $300^{5}$ - a więc zaledwie $3 / 5$ wierszy pierwowzoru, 1928: 254), nie uwzględniają wielu zagadnień (Górnicki pominął między innymi ustępy o wzorowaniu się na języku Petrarki i Boccaccia, o wyrazach przez nich użytych a nieznajdujących się już w obiegu, o archaizmach w literaturze łacińskiej, o wyrażeniach z hiszpańskiego, o doborze słów w języku włoskim, o starzeniu się słów oraz wywód o naśladowaniu, 1928: 254). Górnicki rzeczywiście pominął kilka kwestii poruszonych we włoskim oryginale, ale również wzbogacił wywód Castiglionego. R. Pollak we wstępie do Dworzanina, w przypisach do tego dzieła oraz w dwóch artykułach (Pollak 1928, 1932) wskazuje źródła uwag o języku, z których mógł korzystać Górnicki. Wymienia więc przede wszystkim dialogi: Cycerona De oratore i Speroniego o językach (Dialogo delle lingue Z 1542 r.) oraz dzieła Bemba Prose della volgar lingua (1525) i Kromera De origine et rebus gestis Polonorum (1555). Górnicki, pisząc tę część Dworzanina, wprowadził również do tekstu głównego uwagi pochodzące z obudowy paratekstowej oryginału, to jest $\mathrm{z}$ dedykacji.

Jakie zagadnienia porusza zatem pierwsza polska "nauka o języku”'? Wyrasta ona z krytyki „wydwarzania” (której wady petno wszędziel a podobno u nas w Polszcze więcej niż gdzie indziej, Górnicki 1566: $\mathrm{F}_{2}$ ). Rzeczownik wydwarzanie ${ }^{7}$ został urobiony od czasownika wydwarzać (się), czyli 'przesadzać, sadzić się, afektować się’ i stanowi ekwiwalent włoskiego affettazione $\mathrm{w}$ dziele Castiglionego. Owo wydwarzanie, czyli afektacja, bycie pretensjonalnym, zachowywanie się w sposób nienaturalny i przesadny, dotyczyło nie tylko języka, ale było zjawiskiem o charakterze społeczno-obyczajowym, zawsze wartościowanym negatywnie:

4 Cytaty z utworów Górnickiego podaję w transkrypcji, ale zachowuję zgodną z oryginałem interpunkcję i pisownię wielkich liter. We fragmentach pochodzących z korespondencji autora Dworzanina stosuję pisownię zaproponowaną przez wydawców.

5 W wydaniu Macieja Wirzbięty z 1566 r. karty $\mathrm{F}_{2}-\mathrm{G}$, tj. 15 stron.

6 Referując jej założenia, korzystam z ustaleń Wojciecha Ryszarda Rzepki i Bogdana Walczaka (1993) oraz B. Walczaka (1992, 1995: 169-172).

7 W kartotece toruńskiego oddziału Pracowni SPXVI udokumentowano 19 użyć tego rzeczownika, przy czym wszystkie cytaty pochodzą z Dworzanina polskiego. Czasownik wydwarzać się (poświadczony cztery razy) i imiesłów wydwarzany występują nie tylko w Dworzaninie, ale również w innych źródłach, powstałych po roku 1566 (Postylla domowa Lutra w tłumaczeniu Hieronima Maleckiego 1574, Żywoty świętych Piotra Skargi 1579 oraz O powinnościach wszech stanów ludzi Cycerona w tłumaczeniu Stanisława Koszutskiego 1575). Na tej podstawie można uznać wydwarzanie za neologizm Górnickiego (por. Sinielnikoff 1962).

Za udostępnienie materiałów z tezaurusa Pracowni dziękuję p. dr Patrycji Potoniec kierującej zespołem toruńskim. 
Póty kres niechaj będzie/ mowy około wydwarzania/ bo to każdy z w. m. na oko widzi/ jako szpeci wszelakie postępki człowiecze/ tak te które ciału należą/ jako też te/ które na umyśle zawisły [...] (Górnicki 1566: $\mathrm{G}_{2} \mathrm{~V}$ ).

Wydwarzanie w języku przejawiało się w nadużywaniu funkcjonalnie nieuzasadnionych zapożyczeń. Przykłady wprowadzone przez Górnickiego dobrze ilustrują zjawisko snobizmu i mody językowej:

[...] nasz Polak [...] jeśli był we Włoszech / to za każdym słowem Signor: jeśli we Francyjej/ to/ Per ma foi: jeśli w Hiszpanijej/ to/ Nos otro cavaglieros [...] (Górnicki 1566: $\mathrm{F}_{2}$ ).

Wydwarzanie nie dowodzi znajomości języka obcego, natomiast może świadczyć o pogardliwym stosunku do własnego, rodzimego języka:

A jeśli mu rzeczesz/ żeby swym językiem mówił/ to powieda/ iż zapomniał/ abo że mu sie przyrodzony język prawdziwie gruby widzi [...] (Górnicki 1566: $\mathrm{F}_{2}$ ).

Tymczasem - i jest to chyba najważniejsza teza teorii kultury języka Górnickiego wszystkie języki są równe, nie ma języków z natury swej lepszych i gorszych, są tylko narody bardziej lub mniej zaawansowane w rozwoju kultury (Rzepka, Walczak 1993: 215, 240; Walczak 1992: 126). Wartość każdego języka, czyli jego sprawność komunikatywna, zależy od jego uprawy, wydoskonalenia (Rzepka, Walczak 1993: 218), zatem:

I nasz język Polski rychło by urósł/ gdybyśmy sie go rozmiłowali/ ale nie wiem czemu tak podle rozumiemy o swym języku/ jakoby Łacińskich nauk w się wziąć nie mógł [...] (Górnicki 1566: $\mathrm{F}_{7} \mathrm{~V}-\mathrm{F}_{8}$ ).

Górnicki zwalcza nie tylko to błędne przekonanie, stara się też obalić rozpowszechnione podówczas mity genealogiczne i identyfikacyjne (Walczak 1992: 132; Otwinowska 1974). Proponuje swoisty „wstęp do filologii słowiańskiej” (Walczak 1992: 123), w którym przedstawia koncepcję słowiańskiej rodziny językowej, jej powstania i miejsca w niej polszczyzny:

[...] nasz język nie jest sam w sobie stary/ chocia nim dawno Polacy mówią/ ale urodził sie niedawno barzo z Słowańskiego. Abowiem wszytki te języki/ Polski/ Czeski/ Ruski/ Charwacki/ Bosneński/ Serbski/ Racki/ Bulgarski/ i ine/ Był pirwej jeden język/ jako i naród jeden Słowański [...] (Górnicki 1566: $\mathrm{F}_{4} \mathrm{v}$ ).

W tej koncepcji polszczyzna nie jest (jak dotychczas sądzono) narodową realizacją jednego języka słowiańskiego, nie jest dialektem słowiańskim, lecz odrębnym językiem, choć wywodzącym się wraz z innymi językami słowiańskimi ze wspólnego źródła (Walczak 1992: 125). W tym kontekście pojawia się też „wątek czeski”, kwestia stosunku polszczyzny do języka czeskiego. Okazuje się, że o wyższości języka czeskiego są przekonani sami Polacy: 
[...] urosła im [Czechom - K. T.] ta sława od nas-że samych/ iż ich język miałby byćl dobrze niż nasz/ cudniejszy. jakoż podobno obfitszy niż nasz być może/ a to stąd iż pirwej do nich/ i pismo i nauki przyszły: ale o piękność/ jeszcze to niechaj wisi/ na wyroku (Górnicki 1566: $\mathrm{F}_{5}$ ).

Nie mamy zatem rozstrzygnięcia sporu, który z języków „cudniejszy”: czeski czy polski, natomiast możliwe, że czeszczyzna jest „obfitsza” pod względem zasobu leksykalnego od języka polskiego. O ten aspekt rozwoju języka, o wzbogacenie słownika należy szczególnie zadbać. Górnicki dostrzega dwa źródła wzrostu leksykalnego polszczyzny, tj. zapożyczenia z języków obcych ${ }^{8}$ (głównie z języków słowiańskich, ale także z łaciny, z języka niemieckiego czy włoskiego) oraz wykorzystanie potencjału języka własnego za sprawą archaizmów, neologizmów i dialektyzmów:

[...] gdzieby dzisiejszego słowa nie było na tę rzecz którą by dworzanin opisać chciał/ nie telko mie/ nie obrazi starożytne słowo/ ale je wolę niż cudzoziemskie: na koniec/ i Pruskiem Kaszubskiem słowem/ z których sie więc śmiejemy/ chcę/ aby sie Dworzanin nie hydził: [...]. I to mi sie też nieźle podoba/ kiedy stworzy sobie nowe słowo: ale na Polskim gruncie/ abo ze dwu Polskich jedno uczyni (Górnicki 1566: $\mathrm{F}_{5} \mathrm{v}-\mathrm{F}_{6}$ ).

Znajdziemy w Dworzaninie także uwagi na temat funkcjonalno-stylistycznego zróżnicowania polszczyzny, na temat istnienia dwu podstawowych odmian języka ogólnego, tj. mówionej i pisanej. Trafnie zostały wydobyte różnice między tymi odmianami uwarunkowane typem kontaktu:

[...] gdy mówimy/ ci którzy nas słuchają/ mogą spytać/ jako sie co rozumieć ma/ ale kiedy ja cudze pisanie czytam/ tam gdyż nie masz tego kto pisał/ trudno mam wiedzieć/ co to jest/ czego wyrozumieć nie mogę (Górnicki 1566: $\mathrm{F}_{3}$ ).

Z tym zagadnieniem wiąże się jeszcze jedno pytanie - niestety, pozostające bez odpowiedzi w dyskusji pana Myszkowskiego z panem Kryskim: czy tekst pisany powinien być trudniejszy, bardziej skomplikowany strukturalnie od wypowiedzi ustnej (Rzepka, Walczak 1993: 237-238)? Nie ulega natomiast wątpliwości, że każda wypowiedź, niezależnie od sposobu realizacji, powinna być przemyślana i odpowiednio skomponowana zgodnie z zasadami retoryki, zwłaszcza z zasadą decorum:

[...] mówiąc o obojgu zaraz/ i o mowie/ i o pisaniu/ wszytko to co sie do tych czasów powiedziało/ nic nie jest/ jeśli w każdym związku słów [...] nie będzie znać bystrego rozumu/trefnego wynalazku/ powagi wedle potrzeby/i wszytkiego na wybór. [...] Ani ja też chcę aby zawżdy [dworzanin - K.T.] poważnie mówił/ ale o rzeczach żartownych/ z kunsztem [...]. Zasię gdy o rzeczach wielkich mówić przydzie/ aby poważnie/ rzeźwie/ i potężnie/ mówił/ obierając słowa własne/ jasne/ łatwie/ dobrze złożone/ a te którychby pospolicie używano: abowiem/ też pospolite słowa/ uczynią rzecz ozdobną/ i poważną/ jeśli je dworzanin przerobić/ a usadzić dobrze będzie umiał (Górnicki 1566: $\mathrm{F}_{8} \mathrm{v}-\mathrm{G}$ ).

8 Warto podkreślić, że Górnicki był zwolennikiem wyłącznie pożyczek funkcjonalnie uzasadnionych, zaspokajających rzeczywiste potrzeby nominatywne użytkowników polszczyzny. 
Teoria kultury języka Ł. Górnickiego spotkała się z pewnym odzewem w wieku XVI, zwłaszcza zaś w wieku XVIII. Ślady refleksji o języku autora Dworzanina znajdziemy już w przedmowie Szymona Budnego, skierowanej ku „pobożnemu czytelnikowi” i poprzedzającej ariański przekład Biblii z 1572 r. Do rozważań o języku Górnickiego nawiązali wybitni twórcy oświeceniowi, m.in. Franciszek Bohomolec - autor Rozmowy o języku polskim w dwóch wersjach językowych (łacińskiej i polskiej) z 1758 r. oraz Ignacy Krasicki, który na tematy językowe wypowiadał się na łamach „Monitora”. Z kolei księciu Adamowi Kazimierzowi Czartoryskiemu tak się spodobał „wstęp do filologii słowiańskiej" Górnickiego, że powtórzył go w Historyi nauk wyzwolonych z 1766 r., nie powołując się oczywiście na źródło (Łossowska 1993; Pollak 2004: CXV-CXVI).

2. Z Dworzanina polskiego wydobyłam i omówiłam jedynie podstawowe, główne założenia refleksji o języku polskim Górnickiego - refleksji wielowątkowej, interesującej także w szczegółach. Warto przypomnieć, że wyrasta ona z krytyki wydwarzania. Ale wydwarzanie to nie tylko nadużywanie funkcjonalnie nieuzasadnionych zapożyczeń, to również bezmyślne uleganie szablonowi językowemu (Rzepka, Walczak 1993: 232), hołdowanie przesadnej ceremonialności. W tym sensie miniaturę Raczyl, wydaną w 1598 r. w Oficynie Łazarzowej', można potraktować jako aneks, uzupełnienie uwag o języku w pierwszej księdze Dworzanina ${ }^{10}$. Krytyka wydwarzania zostaje wzmocniona kolejnym przykładem - argumentem: chodzi o nieuzasadnione użycie czasownika raczyć w wypowiedziach mówionych i pisanych ${ }^{11}$. Oto początek Skargi rozumnej mowy na Raczyła przed słowy starożytnemi jako Sędziami wysadzonemi (jak głosi podtytuł):

Do tych czasów cierpiałam ja Panowie Sędziowie, gdy ten Raczył w mniejszych rzeczach miejsce moje sobie przywłaszczał: a com ja zwykła okrągło mówić, i kończyć rzecz jednym słowem, to on koniec ten mnie odejmował, a siebie stawiał: jakoż i teraz odejmuje [...] (Górnicki 1598: 3).

Utwór jest utrzymany w konwencji przemowy sądowej, oskarżycielskiej. Jakub Zdzisław Lichański uznał ją za perełkę retoryczną, świadczącą nie tylko o sprawności pióra Górnickiego, ale i o poczuciu humoru autora (Lichański 1998: 66). Zastosował

9 Dokument dostępny w wersji elektronicznej na stronie Wielkopolskiej Biblioteki Cyfrowej http:// www.wbc.poznan.pl/dlibra/doccontent?id=150078\&from=FBC.

10 I jako dowód wpływu kultury włoskiej na twórczość Górnickiego - w tym wypadku traktatu Giovanniego Della Casa Galateo ovvero décostumi (1558). Więcej na ten temat (Ślaski 1993).

11 Nie tylko Górnicki zwalczał nadużywanie czasownika raczyć - oto sąd Andrzeja Frycza Modrzewskiego (O poprawie Rzeczypospolitej, księga I O obyczajach, rozdział XXV O próżności słów w nazywaniu, w pochlebowaniu i pisaniu listów [...], w tłumaczeniu Cypriana Bazylika): Do łagodnych i pochlebnych mów przystapił i ten obyczaj/ wszytkę naszę mowę raczeniem/ albo waszmościami nadziewać: siebie i swoje służby (bo tak mawiamy) każdemu zalecać: a bez braku każdemu posługil abo uczynności nasze ofiarować (1577: 60). 
Górnicki kilka figur retorycznych. Przede wszystkim posłużył się personifikacją: oskarżycielem jest Mowa Rozumna, oskarżonym - Raczył, sędziami są Starożytne Słowa. Personifikację wspierają dwie figury, które polegają na wprowadzaniu w wypowiedź słów cudzych: prozopopeja (mowę wygłasza upersonifikowane pojęcie) oraz sermocinatio. Przytoczenie rozmów, powiedzeń i myśli innych osób (STL: 466), czyli sermocinatio, odgrywa ważną rolę w najobszerniejszej części całej mowy, w opowiadaniu (narratio), a raczej w uwierzytelnianiu oskarżenia. Przemowę otwiera wstęp (proemium) z apostrofą do Panów Sędziów. Następuje przedstawienie sprawy, a zarazem tematu mowy - oskarżenie Raczyła o wtrącanie się do wszystkiego (Lichański 1998: 66). W epilogu oskarżyciel domaga się najsroższej kary dla Raczyła, ale jaka to kara, właściwie nie wiemy. Czy Raczył zostanie skazany na śmierć, czy na niewolę u Mowy Rozumnej, na niewolę, która jest cięższa niż śmierćn ${ }^{12}$ ? Pozostawmy na razie to pytanie bez odpowiedzi. Kodę, zamknięcie oracji, stanowi parafraza łacińskiej sentencji, pochodzącej z szesnastego listu Horacego: śmierć jest końcem wszytkich kłopotów, wszytkich boleści $i^{13}$. W przemowie mamy do czynienia ze stylem periodycznym ${ }^{14}$. Część introdukcyjna obejmuje trzy periody ${ }^{15}$ (zwieńczone kropką - dwa razy - oraz pytajnikiem), połączone ze sobą dzięki wskaźnikom nawiązania międzywypowiedzeniowego (przeciwstawne ale, wynikowe abowiem). Owe trzy periody zawierają po kilka członów składowych, tj. kolonów. Granice między członami wyznaczają dwa znaki przestankowe: przecinek i dwukropek, przy czym ich funkcje (meta)tekstowe są odmienne. Przecinek wyznacza najniższy hierarchicznie dział treściowo-intonacyjny, odsyła w przód po linii tekstu, zapowiada dalszy ciąg wypowiedzi. Z kolei dwukropek sygnalizuje średni dział treściowo-intonacyjny, odsyła równocześnie w przód i w tył po linii tekstu, wydobywa jedność kompozycyjną członów wypowiedzi (zob. Tutak 2013). Strukturę periodyczną wspiera paralelizm (leksykalny, składniowy i intonacyjny), por. zwłaszcza w trzecim periodzie wstępu:

12 Przeróbka łacińskiej sentencji: Potius mori quam foedari.

13 Księga I: Mors ultima linea rerum est.

14 O stylu periodycznym por. np. (Lausberg 2002).

15 Period, okres w retoryce (podobnie jak zdanie w refleksji składniowej) doczekał się wielu różnych definicji, odwołujących się do kryteriów kompozycyjnych, rytmicznych, semantycznych, logicznych czy syntaktycznych. Za Arystotelesem okresem nazywano taką wypowiedź językową, która posiada swój własny początek i koniec oraz wielkość łatwą do objęcia spojrzeniem (za: Lausberg 2002: 496). W czasach Górnickiego dążono do uściślenia zasad budowy periodu. W dyskusjach na temat cech i struktury okresu brali udział również Polacy, Jakub Górski i Benedykt Herbest. W ujęciu J. Górskiego typowy period retoryczny jest zdaniem złożonym o budowie dwudzielnej i specjalnym, kunsztownym szyku wyrazów, powodującym retardację sensu, w warstwie iloczasowej zaś tworzącym układy miar rytmicznych. [...] Cały okres retoryczny jest pełnym zdaniem gramatycznym. Konstrukcja składniowa i budowa rytmiczna periodu są nierozdzielnie z sobą związane (cyt. za: Werpachowska 1987: 124).

W koncepcji J. Górskiego termin period odnosił się też do rozbudowanego zdania złożonego pozbawionego naddanego uporządkowania rytmiczno-intonacyjnego. Por. (Tutak 2013), gdzie przytoczono między innymi XX-wieczne wykładnie okresu retorycznego. 
[...] że sie wszędy wtrąca, wtrąca sie i tam gdzie potrzeba ukazuje, i tam gdzie mus rozkazuje, i tam gdzie człowiekowi lubo, i tam gdzie przykro? (Górnicki 1598: 3).

W epilogu można wydzielić dwa periody zwieńczone kropką; pierwszy z nich, wprowadzany przez wskaźnik nawiązania międzywypowiedzeniowego przeto, zawiera konstrukcję parentetyczną. Wieloczłonowe, rozbudowane periody we wstępie i zakończeniu zostają zrównoważone i dopełnione krótkimi okresami w korpusie przemowy. W tej części utworu pojawiają się periody proste, jednokolonowe (np. I bez ciebie Raczyła rad ma sen chory każdy, Górnicki 1598: 5), a nawet kommata (Czysty pan, Górnicki 1598: 4). Korpus zawiera 40 przykładów nieuzasadnionego użycia czasownika raczyć, przy czym owe przykłady mają charakter reprodukcji wprowadzanych za pomocą czasowników mówienia. Wykładnikami mowy zależnej są w utworze Górnickiego verba dicendi: mówić, rzec, pytać, odpowiedzieć, przede wszystkim zaś prawić, także $\mathrm{w}$ połączeniu z innymi czasownikami, np. mówit + prawi, pytat + prawi, co według Wojciecha Górnego może świadczyć o zjawisku niewystarczalności wielu czasowników mówienia jako samodzielnych wprowadzeń w staropolszczyźnie (Górny 1966: 343). Zastanawia jednak zestawianie czasowników mówienia w czasie przeszłym z czasownikiem prawić w formie 3. os. 1. poj. czasu teraźniejszego. Krystyna Kleszczowa (1989: 28) uznała takie prawi za przejaw usztywnienia formy wprowadzającej element lokucyjny w opisie aktu mowy, ja dodałabym jeszcze jedną funkcję: parentetyczne prawi może służyć do zaznaczania dystansu wobec reprodukowanej wypowiedzi. Nadawcy takich reprodukowanych wypowiedzi nie zostali skonkretyzowani, występują w tej roli słudzy, innym razem zabiera głos sam Raczył, zawsze jednak mamy do czynienia z niesymetryczną relacją społeczną, w którą wpisuje się czasownik raczyć jako wykładnik grzeczności lub wręcz uniżoności. Taką zrytualizowaną sytuację pragmatyczną sprowadził Górnicki ad absurdum, porównajmy przykłady:

Dopiero prawi Jego M. wstać z łoża raczył. Cóż, abo miał gnić Jego M. dni całe i nocy? (Górnicki 1598: 4).

Dopiero Jego M. umyć sie, dopiero ubrać raczył. Cóż abo nago Jego M. miał chodzić, a bez powagi niemiał sie umyć, abo ubrać? Komuż to kwóli uczynił Jego M. że sie umył, i ubrał? (Górnicki 1598: 5).

Pytał też ktoś przed pokojem jednego pana: Co prawi Jego M. czynić raczy. Odpowiedział mu drugi także mądry. Próznować prawi teraz Jego M. raczy (ibid.).

Tenże też pytał, a wiele stolców Jego M. mieć raczył? A tu Raczyle ${ }^{16}$ co było po tobie? Abo i tu, przepomnieć Jego M. raczył, zgubić raczył, wielkie bolenie głowy Jego M. mieć

16 W wydaniu z 1886 r. Raczyło bez alternacji spółgłoskowej w temacie fleksyjnym. Wydawcy dzieł wszystkich Górnickiego tylko raz zachowali formę wołaczową Raczyle, co więcej, cztery razy zastąpili dopełniacz (bez ciebie Raczyła) wołaczem (bez ciebie, Raczyło). Niestety, Piotr Chmielowski we wstępie do tego wydania nie uzasadnił wprowadzonych zmian. 
raczył. Także i tu, obrazić sie Jego M. tą rzeczą raczył. Pewnieby był wolał Jego M. nie być obrażony (Górnicki 1598: 5-6).

[...] gdy który Senator, rękę, nogę, abo szyję złamie, to sie on i tu wtrąci, i rzecze, z wysoka Jego M. Pan mój szyję złamać raczył: co barzo na szalonego poszło (Górnicki 1598: 7).

Przytoczone wypowiedzi konstytuowane przez raczyć, przeplatane pytaniami retorycznymi i komentarzem odautorskim świadczą o tym, że miniatura Raczył jest chyba najdowcipniejszą ze staropolskich gawęd o języku (Pollak 1961: 40; Rzepka, Walczak 1993: 233).

Jak już wspomniałam, w miniaturze znajduje się 40 przykładów niefortunnego użycia czasownika raczyć. W przytaczaniu tych przykładów można dostrzec pewną gradację. Najpierw pojawiają się dłuższe wypowiedzi z zarysowaną sytuacją komunikacyjną:

Byłam na ten czas w Lublinie na Trybunale, gdy z Podola przyjechał sługa, i prawił nowiny, miedzy któremi i to było (Górnicki 1598: 4).

Na tymże Trybunale słyszałam: [...] (ibid.).

Pytał też ktoś przed pokojem jednego pana: [...]. Odpowiedział mu drugi także mądry (Górnicki 1598: 5).

Widziałam niedawno list tak poczęty: [...] (ibid.).

Do wypowiedzi konstytuowanej przez raczyć zostaje dołączona wypowiedź poprawna, niezawierająca tego czasownika:

Gdyżeś, prawi, W.M. tego czasu doczekać raczył. Azaż nie słuszniej było tak rzec: Gdyżeś W.M. tego doczekał czasu? (Górnicki 1598: 4).

W dalszej części przemowy dominuje wyliczenie, czasownik raczyć występuje w minimalnym kontekście, tj. łączy się z bezokolicznikiem:

[...] pamiętać to Jego M. raczy: żądać raczy: radować sie raczy: w nienawiści mieć raczy: ufać raczy: wielką szkodę mieć raczy: aż i chorować raczy (Górnicki 1598: 5).

Już i do zmysłów sie rzucił, widzieć, słyszeć, jeść, pić, woniać, i dotykać sie Jego M. tego raczył (Górnicki 1598: 6).

Utrwalone w postaci krótkich periodów przykłady ilustrujące niestosowne użycie czasownika raczyć zostają sprowadzone do trzech typów kontekstów. Raczyć nie może pojawić się tam:

1) gdzie co kto rad czyni,

2) gdzie czynić abo cierpieć musi,

3) gdzie czego przyrodzenie potrzebuje (Górnicki 1598: 7). 
Natomiast uzasadnione ze względów funkcjonalnych jest użycie czasownika raczyć tam, gdzie

[...] człowiek, a człowiek wielki, tak, abo owak mogąc uczynić, użyje ludzkości, powagi, i dostojeństwa swego nieco uchyli, do podłej chałupki, do ubogiego gospodarza, na nędzny obiad wstąpi [...]. Abowiem on pan mógł w lepszym gmachu, za kosztowniejszą oponą, w obfitszym domu, przy rozmaitszych potrawach, na rozkoszniejszym trunku siedzieć: co iż opuścił, a mniejsze za więtsze, gorsze za lepsze przyjął, z łaski swej uczynić to raczył (Górnicki 1598: 6).

W ten sposób Górnicki stworzył własną „definicję” czasownika raczyć, wpisał ów czasownik w przestrzeń modalno-aksjologiczną i grzecznościową. Sam autor Dworzanina polskiego nie unikał czasownika raczyć, ale stosował go w sposób świadomy i przemyślany ${ }^{17}$. Potwierdzenie tej obserwacji znajdziemy w utworach dedykacyjnych oraz w korespondencji wydanej w 1886 r. przez Rafała Loewenfelda i P. Chmielowskiego. Raczyć pojawia się przede wszystkim w formułach dewocyjnych, jako element obudowy etykietalnej aktu prośby, rady, podziękowania, życzenia, zalecenia służb, np.:

[...] proszę, żebyś W.M. Jego M. memu M. panu raczył oddać ten fascykułek listów [...] (Loewenfeld, Chmielowski 1886: 281).

Tam W.M. racz posłać o pomoc (Loewenfeld, Chmielowski 1886: 279).

Goście moi M. książę uniżenie W.Ks.M. dziękują, iżeś ich W.Ks.M. przepomnieć nie raczył [...] (Loewenfeld, Chmielowski 1886: 286).

[...] najniższe służby moje W.K.M. [...] zalecam, Pana Boga prosząc, iżby W.K.M. długo na świecie w dobrym zdrowiu i potomstwo W.K.M. chować raczył (Loewenfeld, Chmielowski 1886: 285).

3. Zdaniem W. R. Rzepki i B. Walczaka (1993: 233) w miniaturze Górnickiego na uwagę zasługuje zastosowanie - pierwszy chyba raz w tej skali - przykładów z mówionej, potocznej polszczyzny. Taką opinię zdają się potwierdzać czasowniki mówienia jako wykładniki oratio obliqua oraz konteksty odwzorowujące sytuację komunikacyjną. Dzisiaj trudno jest rozstrzygnąć, czy przywoływane przez Górnickiego przykłady zastosowania czasownika raczyć są autentyczne, z pewnością jednak świadczą o popularności czasownika w drugiej połowie XVI w. Czy tylko w tym okresie raczyć był wyrazem modnym, chętnie stosowanym, wręcz nadużywanym? Odpowiedź na to pytanie powinna przynieść kwerenda słownikowa.

Czasownik raczyć został odnotowany już w SStp, bardzo bogatą dokumentację ma w SPXVI. Zgodnie z ustaleniami autorów SStp raczyć występuje w dwóch znaczeniach, przy czym znaczenie nr 2 poświadcza zaledwie jeden przykład:

17 Wracając do pytania o los Raczyła, możemy stwierdzić, że czeka go nie unicestwienie, lecz podporządkowanie Mowie Rozumnej. 
1) zechcieć coś uczynić kierując się łaskawością, życzliwością, dobrocią;

2) chcieć, pragnąć, życzyć sobie (SStp).

Raczyć 1 konstytuuje głównie modlitewne apostrofy (np. Ociec, syn, duch święty, wsze jeden gospodzin, racz być ze mną i z wami ze wszemi), ale też wcześnie pojawia się w piśmiennictwie świeckim, o czym świadczy fragment listu chana perekopskiego do króla Jana Olbrachta z roku 1500 (Gdyżby nie chciał Dawida posłać, niechaj pośle, ktorego raczy, jinego dobrego człowieka $k$ nam). SPXVI dokumentuje ponad 8 ooo użyć czasownika raczyć w trzech znaczeniach. Jako nowe należy potraktować znaczenie 3.: 'okazywać szacunek, szanować, poważać' (SPXVI), por. wypowiedź pana Kostki w Dworzaninie:

Gdyż tedy mężczyzna w istności swej nie jest doskonalszy niż białagłowa: [...] co sie też przymiotów dotycze/ i w tym białagłowa/ nic jemu naprzód nie da/ jako sie to już pokazało/ nie wiem czemu go w. m. tak barzo raczysz/ a nad białągłowę przekładasz (Górnicki 1566: $\mathrm{X}_{7}$ ).

Owe trzy znaczenia nie wyczerpują jednak potencjału semantycznego czasownika raczyć. Inne znaczenie ujawnił sam Górnicki w wypowiedzi pana Myszkowskiego:

A jako temu przystoi lutnię wziąć w rękę/ gdy o to jest proszony: tak zaś owemu barzo nie przystoi/ który przyszedszy gdzie miedzy ludzie/ zwłaszcza jeśli jeszcze nieznajome/ nie dadząc sie barzo raczyć/ hnet wszytko pokaże co umie/ a czasem i to czego nie umie (Górnicki 1566: Kv).

Raczyć w znaczeniu 'prosić' pojawia się dopiero w SW z kwalifikatorem: wyraz staropolski. Wydaje się, że popularność czasownika raczyć jako składnika zachowań etykietalnych wykracza poza wieki XVI i XVII, o czym przekonują przykłady zaproponowane przez autorów Słownika języka polskiego XVII i 1. połowy XVIII wieku oraz słowników języka Jana Chryzostoma Paska i Adama Mickiewicza. W listach Mickiewicza czasownik raczyć łączy się z innymi wykładnikami grzeczności o charakterze modalnym, np.:

Może będziesz raczyć [...] nie zapomnieć ślicznego ukłonu pannie Aleksandrynie.

Może [...] donieść mi raczysz, jaką drogą mógłbym pisać do niego.

Zrobiłabyś Pani wielką przysługę [...], gdybyś mu je raczyła przesłać.

Zrobiłby on mi wielką przysługę, jeśliby raczył zająć się wyszukaniem dzieła (SJAM).

Nagromadzenie wykładników grzeczności pochodzących z różnych poziomów języka, ale - co ważne - zharmonizowanych, może świadczyć o tym, że czasownik raczyć tracił swoją moc illokucyjną. Jeszcze w SW w artykule raczyć wyróżnia się 
pięć znaczeń czasownika ${ }^{18}$, natomiast w SJPD mamy tylko dwa znaczenia omawianego leksemu:

1) 'częstować, fetować, ugaszczać; podejmować gościnnie' (znaczenie uwzględnione wcześniej w słowniku Lindego i SW);

2) 'chcieć łaskawie co zrobić, uczynić co z łaski swojej' (SJPD) - tu dodano ważny komentarz: „dziś tylko ironicznie, szczególnie z przeczeniem” - to znaczenie ilustruje sześć przykładów z utworów Wasilewskiej (Siedzi rozwalony jak pasza, wstać nie raczy), Kaczkowskiego, Kraszewskiego, Fredry, Rzewuskiego, Mickiewicza.

Witold Doroszewski odnotował także żywy frazeologizm: Bóg raczy wiedzieć, czyli 'nic nie wiadomo, kto to może wiedzieć. W słownikach języka polskiego, które dokumentują pracę leksykografów po W. Doroszewskim, pojawiają się oba znaczenia czasownika raczyć, choć niekiedy z pewnymi modyfikacjami, np. '(ze)chcieć coś zrobić; robić coś niechętnie, z łaski' (Raczył się odezwać) w SWJP oraz w USJP.

W miniaturze Raczył utrzymanej w konwencji przemowy sądowej posłużył się Górnicki sugestywną argumentacją, wspartą doborem figur retorycznych. Walczył w ten sposób ze zwyczajem nieuzasadnionego wykorzystania czasownika raczyć w wypowiedziach mówionych i pisanych. Dawał tym samym kolejny (po Dworzaninie polskim) dowód swej troski o kulturę języka polskiego. Natomiast czasownik raczyć - główny „bohater” utworu Górnickiego - stanowił ważny element językowych zachowań etykietalnych do połowy XIX w. Od tego czasu stopniowo tracił swój potencjał illokucyjny i dziś - jako wykładnik grzeczności - pojawia się w użyciach żartobliwych, nacechowanych ironicznie.

\section{Literatura}

Barycz H., 1950, Wstęp, [w:] Ł. Górnicki, Dzieje w Koronie Polskiej, Wrocław, s. III-LXIV. Berlińska A., 1993, Projekt ortograficzny Łukasza Górnickiego, „Poradnik Językowy” z. 4, s. $166-176$.

Chмielowski P., 1886, Wstęp, [w:] R. Loewenfeld, P. Chmielowski, Łukasza Górnickiego dzieła wszystkie, t. 1, Warszawa, s. V-XXXII.

Gallewicz A., 2006, Dworzanin polski i jego włoski pierwowzór. Studium adaptacji, Warszawa. GóRNICKi Ł., 1566, Dworzanin polski, Kraków.

GóRNICKI Ł., 1598, Raczył, Kraków.

GóRnY W., 1966, Składnia przytoczenia w języku polskim, [w:] A. Wierzbicka, System składniowo-stylistyczny prozy polskiego renesansu, W. Górny, Składnia przytoczenia w języku polskim, Warszawa, s. 283-405.

18 1. Raczyć 'chcieć, woleć; 2. Raczyć co uczynić 'być łaskawym co uczynić, uczynić co z łaski swojej, chcieć łaskawie co zrobić'; 3. Raczyć 'prosić; 4. Raczyć kogo 'być mu radym, podejmować, ugaszczać, częstować, fetować, traktować go uczciwie'; 5. Raczyć kogo 'godnym rozumieć, sądzić; czcić, poważać, szanować, honorować, cenić' (SW). 
GruchaŁa J.S., 1997, Łukasz Górnicki - „Dworzanin polski”, [w:] A. Borowski, J.S. Gruchała (red.), Lektury polonistyczne. Średniowiecze - Renesans - Barok, t. 1, s. 103-129.

KaCZMARCZyк B., 1991, Teoria i praktyka ortograficzna Łukasza Górnickiego, „Rozprawy Komisji Językowej Wrocławskiego Towarzystwa Naukowego” XVII, Wrocław, s. 85-102. KLemensiewiCZ Z., 1981, Historia języka polskiego, Warszawa.

Kleszczowa K., 1989, Verba dicendi w historii języka polskiego. Zmiany znaczeń, Katowice. KozIelewski I., 1929, Łukasz Górnicki. Studium historyczno-literackie, Lwów.

Lausberg H., 2002, Retoryka literacka. Podstawy wiedzy o literaturze, Bydgoszcz.

LiChańsKi J.Z., 1998, Łukasz Górnicki. Sarmacki Castiglione, Warszawa.

Loewenfeld R., Chmielowski P., 1886, Łukasza Górnickiego dzieła wszystkie, t. 1-3, Warszawa. Łossowska I., 1993, Recepcja Łukasza Górnickiego w Oświeceniu, [w:] B. Noworolska, W. Stec (red.), Łukasz Górnicki i jego czasy, Białystok, s. 303-312.

Modrzewski A.F., 1577, O poprawie Rzeczypospolitej ksieggi czwore, Łosk.

Noworolska B., Stec W. (red.), 1993, Łukasz Górnicki i jego czasy, Białystok.

OтwinowsKa B., 1974, Język - naród - kultura. Antecedencje i motywy renesansowej myśli o języku, Wrocław.

Otwinowska B., 1998, Mowa, [w:] T. Michałowska (red.), Słownik literatury staropolskiej. Średniowiecze - Renesans - Barok, Wrocław, s. 562-568.

Pollak R., 1928, Uwagi o języku polskim w „Dworzaninie” Górnickiego, [w:] Studia staropolskie. Księga ku czci Aleksandra Brücknera, Kraków, s. 252-262.

Pollak R., 1932, Dokoła pierwszej polskiej „nauki o języku”, „Pamiętnik Literacki” XXIX, Z. 3-4, s. 302-318.

Pollak R., 1961, Wstęp, [w:] Ł. Górnicki, Pisma, t. 1, Warszawa, s. 5-45.

Pollak R., 1984, Dworzanin polski, [w:] J. Krzyżanowski (red.), Literatura polska. Przewodnik encyklopedyczny, t. 1, Warszawa, s. 218.

Pollak R., 2004, Wstęp, [w:] Ł. Górnicki, Dworzanin polski, t. 1, Wrocław, s. V-CXXXI.

Rospond S., 1949, Studia nad językiem polskim XVI wieku (Jan Seklucjan, Stanisław Murzynowski, Jan Sandecki-Malecki, Grzegorz Orszak), Wrocław.

Rzepka W.R., Walczak B., 1993, Łukasza Górnickiego teoria kultury języka, [w:] B. Noworolska, W. Stec (red.), Łukasz Górnicki i jego czasy, Białystok, s. 211-243.

SAlwa P. (red.), 2005, Łukasz Górnicki i jego włoskie inspiracje, Warszawa.

Sierotwiński S., 1986, Słownik terminów literackich. Teoria i nauki pomocnicze literatury, Wrocław.

Sinielnikoff R., 1962, Z badań nad kultura językowa XVI wieku. Nazwy pojęć w „Dworzaninie” Górnickiego, „Poradnik Językowy” z. 1, s. 1-12.

SJAM: K. Górski, S. Hrabec (red.), Słownik języka Adama Mickiewicza, Wrocław - Warszawa - Kraków 1962-1983.

SJPD: W. Doroszewski (red.), Słownik języka polskiego, Warszawa 1958-1969.

SPXVI: Słownik polszczyzny XVI w., t. I-IV red. komitet redakcyjny, t. V-XVII red. M.R.

Mayenowa, t. XVIII-XXXII red. F. Pepłowski, Wrocław - Warszawa - Kraków 1966-2010.

SSтр: S. Urbańczyk (red.), Słownik staropolski, Kraków 1953-2002.

STL: J. Sławiński (red.), Słownik terminów literackich, Wrocław 1988.

SW: J. Karłowicz, A. Kryński, W. Niedźwiedzki (red.), Słownik języka polskiego, Warszawa 1900-1927.

SWJP: B. Dunaj (red.), Słownik współczesnego języka polskiego, Warszawa 1998. 
ŚLASKi J., 1993, Italianizm Łukasza Górnickiego, [w:] B. Noworolska, W. Stec (red.), Łukasz

Górnicki i jego czasy, Białystok, s. 31-69.

TuтAк K., 2013, O dedykacjach $w$ drukach polskich XVI i XVII wieku (grafia i interpunkcja), „Biblioteka »LingVariów«” t. 16, Kraków.

USJP: S. Dubisz (red.), Uniwersalny słownik języka polskiego, Warszawa 2003.

WalczaK B., 1992, Pierwszy polski wstęp do filologii słowiańskiej, [w:] J. Brzeziński, P. Suder

(red.), XVII Konferencja młodych językoznawców Język - teoria - dydaktyka, Zielona

Góra, s. 123-132.

Walczak B., 1995, Zarys dziejów języka polskiego, Poznań.

Werpachowska A., 1987, Z dziejów retoryki XVI wieku. Polemika Jakuba Górskiego z Benedyktem Herbestem, Wrocław.

\section{Kukasz Górnicki's Raczył 'He deigned' in the light of the linguistic culture theory of the author of Dworzanin polski 'The Polish courtier' Summary}

The paper consists of three parts. The first one introduces the basic assumptions of the linguistic culture theory, the first Polish linguistic guide, as it was reconstructed on the basis of Łukasz Górnicki's Dworzanin polski 'The Polish courtier' (1566). The second part discusses Górnicki's miniature Raczyt 'He deigned' (1598) which, too, is evidence of his interest in linguistic matters. The paper draws attention to the rhetoric shape of the work which, as a whole, follows the convention of a judicial speech. The third part of the paper presents the results of a study of the verb raczyć, based on a dictionary query. 